\title{
ВТІЛЕННЯ ПСИХОЛОГІЧНИХ ОСОБЛИВОСТЕЙ ПРАЦІВНИКА ОПЕРАТИВНО-РОЗШУКОВОЇ ДІЯЛЬНОСТІ В ПРАВОВУ СВІДОМІСТЬ
}

\author{
Чухраєва Ганна Вікторівна ${ }^{1}$
}

\begin{abstract}
${ }^{1}$ Кандидат медичних наук, начальник Центру психіатричної допомоги та професійного психофізіологічного відбору, Державна Установа «Територіальне Медичне Об'єднання по Харківській області», м. Харків (Україна)

ORCID ID: https://orcid.org/0000-0001-8646-8680
\end{abstract}

UDC: $159.9:[351.741: 343.102]$

\begin{abstract}
АНОТАЦІЯ
Стаття присвячена визначенню основних психологічних особливостей особистості працівника поліції всіх підрозділів поліції, і особливо, виокремити ці аспекти у працівників з оперативно-розшуковою діяльністю. На основі проведених емпіричних досліджень встановлено, що оперативно-розшукова діяльність пов'язана з високою правовою відповідальністю і свідомістю, які межують з високим ризиком водночас.
\end{abstract}

Мета статті: Метою даного дослідження є визначення основних психологічних особливостей особистості поліцейського з оперативно-розшуковою діяльністю, які формують високу правову свідомість, не звертаючи увагу на часті ситуації, як пов'язані з ризиком.

Методи дослідження: Працівникам поліції, особливо працівникам з оперативно-розшуковою діяльністю, були проведені психодіагностичні обстеження за методиками МБДО, а також емпіричні дослідження, такі як співбесіда, методи нагляду.

Висновки. Захист інтересів держави та інтересів громадян, які виконують працівники поліції, особливо працівники з оперативно-розшуковою діяльністю, пов'язаний з високою правовою свідомістю і відповідальністю, які в першу чергу формуються на основі основних психологічних особливостей особистості поліцейського. При проведених психологічних обстеженнях працівникам поліції спеціальних підрозділів і працівників з оперативно-розшуковою діяльністю можна зазначити, що такими спільними рисами $€$ прагнення до лідерства, суперництва, домінування, подолання перешкод, самостійності в прийнятті рішень і дій. Високий рівень пошукової активності, прагнення до незалежності, вільної поведінки, безпосередності. В умовах емоційного залучення - чітко виражені протилежні емоції. Мотив досягнення успіху пов'язаний з волею до реалізації сильних бажань; схильність до ризику. Висловлення й дії не можуть випереджати планомірну і послідовну продуманість учинків. Можна з впевненістю зазначити, що така риса

Address for correspondence, e-mail : editpsychas@gmail.com

Copyright: (C) Anna Chuhraeva

This is an Open Access journal, all articles are distributed under the terms of the Creative Commons AttributionNonCommercial-ShareAlike 4.0 International (CC BY-NC-SA 4.0) License (http://creativecommons.org/licenses/by-nc$\mathrm{sa} / 4.0 /$ ), allowing third parties to copy and redistribute the material in any medium or format and to remix, transform, and build upon the material, provided the original work is properly cited and states its license. 


\begin{abstract}
характеру, як схильність до ризику, особливо притаманна працівникам поліції спеціальних оперативних підрозділів. Для працівників пспеціальних підрозділів поліції більш характерні: схильність до ризику, здатність і схильність до високої активності, невимушеності в спілкуванні, ініціативності, ризику. Прагнення бути в центрі уваги, максимально інформованим. Енергійність, висока працездатність, витривалість, організаційні здатності. їхнє лідерство зазвичай сприймається оточуючими як природне явище. Добре розвинені навички спілкування.

Оперативно-службові завдання, що стоять, наприклад, перед працівниками кримінальних та слідчих підрозділів, вимагають прояву специфічних професійних якостей, найважливішими з яких є здатність до адекватної самооцінки. У працівників поліції, представників цих двох професійних груп, мають бути сформовані деякі соціально-професійні якості, що дозволяють їм успішно виконувати складні завдання, взаємодіяти з іншими людьми.
\end{abstract}

Ключові слова: правова свідомість; ризик; психологічні особливості; особистість; поліція.

Постановка проблеми полягає в тому, що питання професійної свідомості та питання професійного ризику не мали можливості практично визначити ці поняття.

Аналіз останніх досліджень і публікацій. Більшість дослідників сходяться на тому, що в прояві професійної правосвідомості працівників поліції особливе місце займають психологічні чинники. Проблема професійної правової свідомості працівників Національної поліції України розкривається в дослідженнях В.Л. Васильєва та інших (Vasilev, 1995).

За даними I. В. Ващенко, коли дії в ситуації ризику працівника поліції спричинюють неочікуваний результат, а негативні наслідки у вирішенні проблем, в певної особистості виникають «особистісні особливості, що визначають схильність до переживання почуття провини».
За К. К. Платоновим «особистість - це людина як носій свідомості» (Platonov, 1970, 1982).

Н. В. Гришина у своїх працях, пов'язаних 3 дослідженням проблеми особистості, зазначає, що психологічне вивчення особистості взаємопов'язане з дослідженням творчих моментів людської діяльності, розуміння яких дасть змогу надати психологічну характеристику й визначення особистості (Gryshyna, 2008).

Мета статті: Метою даного дослідження є визначення основних психологічних особливостей особистості поліцейського 3 оперативно-розшуковою діяльністю, які формують високу правову свідомість, не звертаючи увагу на часті ситуації, як пов'язані з ризиком.

Методи дослідження: Працівникам поліції, особливо працівникам 3 оперативнорозшуковою діяльністю, були проведені пси- 
ходіагностичні обстеження за методиками МБДО, а також емпіричні дослідження, такі як співбесіда, методи нагляду.

Перебуваючи в центрі соціальнополітичних процесів, працівники Національної поліції України в силу специфіки свого соціального положення покликані захищати як права і інтереси громадян відповідно до закону, так і інтереси держави, надавати соціальну допомогу різним категоріям населення. Психологічний аналіз діяльності працівників 3 оперативно-розшуковими функціями діяльності дозволяє зробити висновок про іiі складність, багатовимірність, інтенсивний і експресивний характер. Знання загальних закономірностей діяльності як соціально-професійного феномену сприяє розумінню процесів ії здійснення та підвищення ефективності.

Специфіка професійного становлення працівників Національної поліції України, яка полягає в тому, що важливим є їх розвиток не тільки як професіоналів, що володіють професійно важливими особистісними властивостями, але і як особистостей з особливими морально-вольовими, громадянськими якостями, готовністю до правоохоронної діяльності, сформованої професійної правової культурою і правосвідомістю, новоутворенням якого $\epsilon$ професійна правова свідомість (Platonov, 1982).

Проблема професійної правової свідомості працівників Національної поліції України розкривається в дослідженнях В.Л. Васи- льєва та інших (Vasilev, 1995).

Більшість дослідників сходяться на тому, що в прояві професійної правосвідомості працівників поліції особливе місце займають психологічні чинники. Правова ідеологія по відношенню до психологічної складової правової свідомості не завжди відіграє основну роль. Правова свідомість працівника поліції представлена системою почуттів, установок, поглядів, ціннісних орієнтацій, уявлень та іiі інших складових.

Вивченням правосвідомості працівника поліції займається правова психологія, а саме: вивчає закономірності розвитку і функціонування правосвідомості та правослухняної поведінки людини, змін цієї поведінки у зв'язку 3 соціально-економічними реформуваннями в структурі суспільства (Meryshchuk, 1982).

Сформованість професійної правової свідомості є основним чинником серед чинників свідомості працівника 3 оперативнорозшуковими функціями діяльності. Служба в поліції є однією з самих складних в силу різних причин, тим паче, вона залишається низько оплачуваною і на сьогоднішній день. Цей чинник $є$ негативним в першу чергу тим, що не дозволяє залучити на службу високоінтелектуальну та перспективну частину молоді, яка намагається знайти себе на інших ділянках діяльності. Тим не менше професія потребує від людини великої віддачі, так як відрізняється непомірно великою фізичною, емоційною, моральною напругою, ненормованим робочим 
днем, ризиком для життя та здоров'я (Berestovoi, 2006).

Службова діяльність осіб рядового та начальницького складу пов'язана 3 підвищеною відповідальністю працівників за свої дії. Під час виконання службового обов'язку працівникам нерідко доводиться знаходитися в ситуаціях 3 непередбачуваним результатом, які характеризуються недостатньою визначеністю рольових функцій, психічними і фізичними перевантаженнями, необхідністю спілкуватися 3 найрізноманітнішим контингентом громадян і вимагає від працівника рішучих дій і здатності піти на ризик.

Найчастіше працівників поліції провадиться в напружених умовах, конфліктних ситуаціях, небезпечних для життя обставинах.

Якщо працівник спецпідрозділу поліції володіє емоційно-вольовою

стійкістю, він легше долає психологічні наслідки невдач і зривів (Bandurka, 2006).

Зрозуміло, що більше позитивних («ділових») якостей має людина, то швидше вона буде досягати будь-яких цілей. Тому розвиток цих якостей повинен бути пріоритетним у розвитку особистості працівника поліції.

Особистість - це системна якість, яку здобуває суб'єкт (індивід) у системі діяльностей, що здійснюють його життя в суспільстві й у системі об'єктивних відносин суспільства (Barko, 2007).
За К. К. Платоновим «особистість - це людина як носій свідомості» (Platonov, 1970, 1982).

Н. В. Гришина у своїх працях, пов'язаних 3 дослідженням проблеми особистості, зазначає, що психологічне вивчення особистості взаємопов'язане $з$ дослідженням творчих моментів людської діяльності, розуміння яких дасть змогу надати психологічну характеристику й визначення особистості (Gryshyna, 2008).

Відповідно до «Закону про Національну поліцію України» ст. 29 «Основні принципи служби в Національній поліції України» одними з основних принципів працівника поліції є професіоналізм, компетентність, ініціативність відданість справі, а також особиста відповідальність за свої власні дії і за незаконність або бездіяльність.

Тому в екстремальних ситуаціях, коли обмаль часу для прийняття рішень та дій рівень професіоналізму, компетентності є запорукою позитивного результату в випадках ризику.

Ризик - це поняття, яке залежить від емоційної стійкості, від особистісних особливостей особистості, від його інтелектуальних здібностей та деяких інших. Динамічні особливості психічної діяльності залежать від емоції і від волі. Тому вони визначаються відношенням емоційних і вольових особливостей. Ризик може бути і необхідним, і невиправданим (Platonov, 1970). 
Розумна схильність до ризику - це швидкість реакції, вміння орієнтуватися в складній обстановці.

Ризик - ситуативна характеристика діяльності, що полягає в невизначеності iii peзультату і можливих несприятливих наслідках в разі неуспіху (Platonov, 1982).

Ризик характеризується можливістю вибору між менш або більш небезпечними для працівника поліції варіантами поводження, але розрізняються за ступенем їхньої ефективності $з$ погляду досягнення результатів діяльності.

Часто ризиковане поводження дає змогу досягти мети діяльності швидше й з мінімальними втратами. Самі види ризику різноманітні: ризик зриву рішення службового завдання, ризик одержання стягнення, ризик звільнення 3 посади, ризик одержання фізичного ушкодження, ризик для свого життя, ризик для свого авторитету й морального престижу й ін. (Platonov, 1982).

За даними I. В. Ващенко, коли дії в ситуації ризику працівника поліції спричинюють неочікуваний результат, а негативні наслідки у вирішенні проблем, в певної особистості виникають «особистісні особливості, що визначають схильність до переживання почуття провини».

Спірним було питання, чи дасть змогу методика виявити особистісні властивості індивіда або особливості його стану. Сьогодні більшість дослідників уважає, що особливості стану значною мірою визначаються індивідуальним типом реагування й виявляються посиленням, загостренням або ослабленням особистісних якостей (Sliedkov, 1997).

У сучасних умовах від працівників поліції вимагається: посилення професійного потенціалу, забезпечення психологічної готовності до екстремальних ситуацій та уміння своєчасно реагувати на ситуацію, захищаючи правопорядок. У період проведення реформування, яке торкається всієї системи правопорядку МВС психологічне навантаження на працівників системи ще більше зростає.

3 огляду на професійну діяльність працівників 3 оперативно-розшуковими функціями, їх служба $є$ найбільш небезпечною та складною. Ці працівники повинні мати високу мотивацію досягнень, впевненість у собі, позитивну самооцінку, зокрема рішучість, яка близька схильності до ризику, а значить і високу ступінь адаптації.

Функція адаптації визначається переважно двома чинниками, а саме: прагненням особистості до самореалізації, до досягнення мети й задоволення потреб у протидії Діючим чинникам середовища, що обмежують самореалізацію особистості, а також тенденцію до підвищеного самоконтролю 3 відмовою від досягнення потреб заради збереження конкрентних відносин з оточенням. Перевага показників стенічної самореалізації може спричинювати порушення адаптації за соціальноповедінковим типом насамперед, гіпостеніч- 
ний стан означає відмову від самореалізації й перевагу соціального тиску і тиску середовища на особистість, що сприяє виникненню невротичного патерну дезадаптації. В разі перенапруження тих й інших тенденцій відбувається взаємне їхнє зниження. Блокованими виявляються невротичний і поведінковий відвідні канали, які відреагували в емоційному регістрі, що приводить до дезадаптації.

Працівникам поліції, особливо працівникам 3 оперативно-розшуковою діяльністю, були проведені психодіагностичні обстеження за методиками МБДО, а також емпіричні дослідження, такі як співбесіда, методи нагляду. Нами були отримані наступні результати 3 даними психологічних особливостей даних працівників поліції. Прагнення до лідерства, суперництва, домінування, подолання перешкод, самостійності в прийнятті рішень і дій. Високий рівень пошукової активності. Прагнення до незалежності, вільної поведінки, безпосередності. В умовах емоційного залучення - чітко виражені протилежні емоції. Мотив досягнення успіху пов'язаний з волею до реалізації сильних бажань; схильність до ризику. Висловлення й дії не можуть випереджати планомірну і послідовну продуманість учинків. Можна 3 впевненістю зазначити, що така риса характеру, як схильність до ризику, особливо притаманна працівникам поліції спеціальних оперативних підрозділів. Для працівників пспеціальних підрозділів поліції більш характерні: схильність до ризику, здатність і схильність до високої активності, невимушеності в спілкуванні, ініціативності, ризику. Прагнення бути в центрі уваги, максимально інформованим. Енергійність, висока працездатність, витривалість, організаційні здатності. їхнє лідерство зазвичай сприймається оточуючими як природне явище. Добре розвинені навички спілкування.

Особи рядового та начальницького складу підрозділу БПОП (колишнього СПШР) - більш рішучі, життєрадісні, владні, мають егоїстичний тип особистості, у них переважають: соціальна пристосованість, широке коло інтересів, сценічність, багата уява, наполегливість, упертість, виражене прагнення до емоційного залучення, сензитивність до критичних зауважень i зовнішніх впливів, схильність до перебільшення своїх можливостей, невимушеність у спілкуванні, здатність висловлювати свою думку, готовність поділитися враженнями.

Ці специфічні особливості професійної діяльності роблять значний вплив на особистісні характеристики іï представників і можуть призводити до негативних соціальнопсихологічних наслідків (Chukhraeva, 2014).

Оперативно-службові завдання, що стоять, наприклад, перед працівниками кримінальних та слідчих підрозділів, вимагають прояву специфічних професійних якостей, найважливішими 3 яких є здатність до адекватної самооцінки. У працівників поліції, представників цих двох професійних груп, мають 
бути сформовані деякі соціально-професійні якості, що дозволяють їм успішно виконувати складні завдання, взаємодіяти з іншими людьми. У такому розумінні соціально-професійні групи - це сукупність фахівців, професійна діяльність яких пов'язана із спілкуванням i взаємодією з людьми. Специфічність соціально-професійних груп працівників Національної поліції України являє собою особистісні якості, які проявляються в адекватності рішення (стандартних та які вимагають творчого підходу). Професійна ідентифікація особистості працівника Національної поліції України залежить, в першу чергу, від професійної самосвідомості як системи особистісних якостей, які демонструються в професійній діяльності всьому суспільству. Відповідність професійної ролі і особливостей особистості працівників є структурно-функціональною відповідністю, на підставі якої функціонує професійно-особистісна модель працівника в громадській думці. Деформація структурнофункціональної відповідності професійної ролі працівників Національної поліції України і їх особистісних проявів викликає суспільну потребу в корекції відповідності ролі і поведінки службовця (Vasilev, 1995).

Так, у процесі вирішення оперативнорозшукових завдань оперуповноважений працівник та слідчий часто змушений впливати специфічно та психологічно на різні категорії громадян, зокрема, для отримання оперативної інформації в процесі спілкування з конфі- денційними джерелами, в ході опитувань і допитів, що висуває дуже високі і різносторонні вимоги до особистості працівника, а наявність знань і вмінь у сфері комунікативної взаємодії та вирішення конфліктних ситуацій при здійсненні профілактичних завдань відіграють величезну роль. Вивчення особистісних особливостей працівників Національної поліції України - представників різних соціальнопрофесійних груп залежно від соціальнодемографічних і професійних характеристик $\epsilon$ головною складовою для реалізації психологічного потенціалу особистості працівників і соціально-психологічного супроводу їх діяльності, особливо для працівників Національної поліції України 3 оперативно-розшуковими функціями діяльності (Chukhraeva, 2014).

Якщо усвідомлення особистістю свого зв'язку з групою своєї спільноти відіграє роль спонукання і емоційно забарвлене, то загальні елементи у змісті свідомості членів групи значною мірою регулюють їх спільну діяльність. Отже, якщо на рівні самооцінок не забезпечується єдиної подібності, цілісності, то не виникає передумов для формування професійної групової свідомості. Залежність станів групової свідомості від рівня розвитку групи безсумнівна (Platonov, 1982).

У разі великої кількості міжособистісних контактів у різних сферах, $є$ імовірність нетривалого, поверхневого спілкування. Здатність переносити неминучі труднощі в спілкуванні без реакцій тривоги і пригніченості. Ви- 
ражені схильність до пригод, хоробрість, наполегливість, упертість, заповзятливість, прагнення до подолання перешкод, самоствердження; постійне прагнення до зовнішньої збудливої ситуації. Властива демонстрація мужнього стилю життя, сили, витривалості, зневаги до дріб'язків, наполегливості. Є значущим соціальний престиж. Не виключена підвищена чутливість стосовно дійсних або уявних несправедливостей. Характерні життєрадісність, рішучість, упевненість у собі, владність, екстравертованість, честолюбство. Прагнення керуватися твердим наміром бути кращим, розумнішим від інших, лідирувати в груповій діяльності. Для задоволення честолюбства необхідні реальні досягнення й результати, що підтверджують престиж і значущість.

У широкому плані поняттям професійної свідомості можна визначити всі ті прояви свідомості особистості, які пов'язані з іiі професійною діяльністю. Вони визначаються: місцем і значенням даної професії в професійній структурі суспільства; ставленням особистості до професії, іï представникам і до себе як професіонала; професійними ідеалами. Більшість авторів вкладають в це поняття усвідомлення людиною своєї приналежності до певної професійної групи та трактують його як вибіркову діяльність самосвідомості особистості, підпорядковану завданню самовизначення; усвідомлення себе як суб'єкта професійної діяльності. У цьому випадку стають очевидними дві головні особливості суб'єкта даної діяльності. По-перше, він набуває рис полісуб'єктності, знаходить статус колективного (групового) суб'єкта. По-друге, суб'єкт стає при цьому не тільки «множинним» i «розподіленим», але і організованим. Завдяки рефлексивним властивостям і процесам відбувається не тільки диференціація - виділення індивідуального суб'єкта («Я сам»), а й стає можливою їх подальша інтеграція в рамках колективного суб’єкта («Ми разом») (Shestov, 1992).

Ми розуміємо під груповою професійною свідомістю працівника поліції усвідомлення себе в системі своєї професійної діяльності, в системі професійного спілкування та взаємодії з населенням, в системі власної особистості.

\section{Висновки.}

Захист інтересів держави та інтересів громадян, які виконують працівники поліції, особливо працівники 3 оперативнорозшуковою діяльністю, пов'язаний 3 високою правовою свідомістю і відповідальністю, які в першу чергу формуються на основі основних психологічних особливостей особистості поліцейського. При проведених психологічних обстеженнях працівникам поліції спеціальних підрозділів і працівників з оперативнорозшуковою діяльністю можна зазначити, що такими спільними рисами $€$ прагнення до лідерства, суперництва, домінування, подолання перешкод, самостійності в прийнятті рішень i 
дій. Високий рівень пошукової активності. прагнення до незалежності, вільної поведінки, безпосередності. В умовах емоційного залучення - чітко виражені протилежні емоції. Мотив досягнення успіху пов'язаний з волею до реалізації сильних бажань; схильність до ризику. Висловлення й дії не можуть випереджати планомірну і послідовну продуманість учинків. Можна $з$ впевненістю зазначити, що така риса характеру, як схильність до ризику, особливо притаманна працівникам поліції спеціальних оперативних підрозділів. Для працівників спеціальних підрозділів поліції більш характерні: схильність до ризику, здатність і схильність до високої активності, невимушеності в спілкуванні, ініціативності, ризику. Прагнення бути в центрі уваги, максимально інформованим. Енергійність, висока працездатність, витривалість, організаційні здатності. їхнє лідерство зазвичай сприймається оточуючими як природне явище. Добре розвинені навички спілкування.

Оперативно-службові завдання, що стоять, наприклад, перед працівниками кримінальних та слідчих підрозділів, вимагають прояву специфічних професійних якостей, найважливішими 3 яких є здатність до адекватної самооцінки. У працівників поліції, представників цих двох професійних груп, мають бути сформовані деякі соціально-професійні якості, що дозволяють їм успішно виконувати складні завдання, взаємодіяти з іншими людьми.

\section{References:}

Bandurka, A. M. (2006). Professionalism i liderstvo [Professionalism and leadership]. Kharkiv: Title. [in Russian]

Barko, V.I. (2007) Professiograficheskoe opisanie osnovnykh vidov deiatelnosti v OVD Ukraine [The professiographic description of the main activities in the Department of Internal Affairs of Ukraine]. Kyiv : KNUVD, Tipografiia MVD. [in Russian]

Berestovoi, S. G. (2006) Socialno-psychologicheskie predstavleniia o kachestve zhizni $\mathrm{v}$ professionalnom prostranstve OVD [Socio-psychological ideas about the quality of life in the professional space of the Department of Internal Affairs]. Kostroma. [in Russian]

Vasilev, V. L. (1995) Sistemnyy professiograficheskiy podkhod $\mathrm{k}$ podboru $\mathrm{I}$ rasstanovke kadrov pravookhranitelnykh organov [Socio-psychological ideas about the quality of life in the professional space of the Department of Internal Affairs]. Materials mezhdunar.nauch. prakt. konf. SanktRetergurg. 65-70. [in Russian]

Gryshyna, N. V. (2008) Psykhologiia konflikta [Psychology of conflict]. Sankt-Pereburg.: Piter. [in Russian]

Meryshchuk, L.V. (1982) Psychologicheskie osnovy formirovaniia professionalno znachimykh kachestv; diss. Dokt. Psikhol. nauk / Meryshchuk V.L.,.-351 s. [in Russian]

Platonov, K. K. (1970). Necessary clarifications (about the methodical problems of professional selection in a professional orientation) [Necessary clarifications (on methodological problems of professional selection in professional orientation) ]. Socialnie trudiy [Socialistic labour]. 10. 94 - 100. [in Russian]

Platonov, K. K. (1982) Neobkhodimye utochneniia (o 
metodicheskikh problemakh professionalnogo otbora $\mathrm{v}$ professionalnoi orientatsiyi [Psychology system and theory of reflection]. Moscow: Nauka. [in Russian]

Sliedkov, E. V. (1997) Boieviaa travma (Klinikopatogenetychna dunamika, diagnostyka, Likuvalnoreabilitatsiini pryntsypy) [Combat psychic trauma (clinical and pathogenetic dynamics, diagnostics, treatment and rehabilitation principles)]. SanktPeterburg. [in Russian]

Chukhraeva, G. V. (2014) Psychologichni osoblivosti skhylnosti do rozvytku professiinoi deformazii osobustosti [Psychological features of the propensity to develop

professional deformation of the personality]. Naukovyi Visnyk Mykolaivskoho Nationalnoho universitetu im. V.O. Sukhomlinskogo. 2.12 (103). 235-238. [in Ukrainian]

Chukhraeva, G. V. (2014) Sozialno-psychologichni osoblivosti yakosti zhuttya prazivnykiv OVS [Socio -psychological features of the quality of life of the police officers] Visnyk Nazionalnogo universitetu oborony Ukrayiny. Kharkiv. 2. 313-318. [in Ukrainian]

Shestov L. (1992) Kirkergard I ekzistentsialnaya filosofiya. Moscow. [in Russian]

\section{Chuhraeva Anna}

PhD in Medical Sciences, Head of the Centre of Psychiatric Help and Professional Psycho-Physiological Selection, State Institution "Territorial Medical Association at the Ministry of Internal Affairs of Ukraine in Kharkiv region", Kharkiv (Ukraine)

\section{EMBODIMENT OF PSYCHOLOGICAL FEATURES OF INVESTIGATORY WORKERS INTO THEIR LEGAL CONSCIOUSNESS}

\section{ABSTRACT}

Introduction. The article determines the basic psychological features of police workers from all police subdivisions and, especially, distinguishes the examined aspects characteristic for investigatory workers. The conducted empiric research shows that investigatory work is related to high legal responsibility and consciousness and to a high risk, at the same time.

Purpose. The research aim is to determine basic psychological features of police officers from investigatory departments that support their high legal consciousness in spite of frequent risky situations.

Methods. Psycho-physiological diagnostic of police workers, especially investigatory workers, was performed with the special MBDO methods, as well as their interviewing and supervision was used.

Originality of the proposed research is in the fact that professional consciousness and risk have been examined not only from the scientific position, but also in connection with the psychological features of police officers revealed with the psychophysiological diagnostic. 
Conclusion. Defence of interests of the state and its citizens, which is the main task of police officers and investigating workers, especially, is related to high legal consciousness and responsibility. Such traits are formed, first of all, on the basic psychological features of police officers. The performed psycho-physiological diagnostic of police officers from special subdivisions and investigating workers has revealed their general characteristics, such as: aspiring to leadership, rivalry, dominance, overcoming of obstacles, independence in decision making and actions, deep diving into investigative tasks, aspiring is independence, independents behaviour, and spontaneity. Achievement motivation is supported by strong desire for task fulfilment and propensity to risk. Their statements and actions cannot go ahead systematic and carefully planning. We should note that the police workers from the special operative (investigatory) subdivisions manifest often such personal trait as propensity to risks. The police workers of these subdivisions are characterised by: propensity to the risk, capacity and inclination for high performance, sociability, initiative. They want to be at the centre of attention and to be as knowledgeable as possible. They are characterised by psychological hardiness and good organizational abilities. Their leadership is usually perceived by others as natural.

Operative official tasks applied on the workers of investigatory subdivisions require the specific professional qualities, and adequate self- estimation is the most important one. They also should have the social-professional qualities that allow them to execute successfully difficult tasks and co-operate with other people.

Key word: legal consciousness; risk; psychological features; personality; police.

\section{Чухраева Анна Викторовна}

Кандидат медииинских наук, начальник Центра психиатрической помощи и профессионального психофизиологического отбора, Государственное Учреждение «Территориальное Медицинское Объединение по Харьковской области», г. Харьков (Украина)

\section{ВНЕДРЕНИЕ ПСИХОЛОГИЧЕСКИХ ОСОБЕННОСТЕЙ СОТРУДНИКОВ ОПЕРАТИВНО-РОЗЫСКНОЙ ДЕЯТЕЛЬНОСТИ В ПРАВОВУЮ СОЗНАТЕЛЬНОСТЬ}

\section{АННОТАЦИЯ}

Статья посвящена определению основных психологических особенностей сотрудника полиции всех подразделений полиции, а особенно, выделить эти аспекты у сотрудников с оперативно-розыскной деятельностью. На основании проведенных эмпирических исследований определено, что оперативнорозыскная деятельность связана с высокою правовою ответственностью и сознательностью, которые граничат с высоким риском одновременно.

Оперативно-служебные задания, которые стоят, например, перед сотрудками криминальных и следственных подразделений, 
требуют проявления специфических профессиональных качеств, важнейшей из которых является способность к адекватной самооценке. У сотрудников полиции, представителей этих двух профессиональных групп, должны быть сформированы некоторые социальнопрофессиональные качества, которые позволяют им успешно выполнять сложные задания, взаимодействовать с другими людьми.

Ключевые слова: правовая сознательность; риск; психологические особенности; личность; полиция. 